IN3 Working Paper Series

INTERNET INTERDISCIPLINARY INSTITUTE

ISSN 2013-8644

\title{
Psychosocial work factors and older workers' health in Europe
}

Daniel Blanche (dblanchet@uoc.edu)

Internet Interdisciplinary Institute (IN3)

Open University of Catalonia (UOC)

Working Paper

Working Paper Series WP15-003

Research group: Mobile Technologies and (G)Local Challenges (GLocalMob)

Research group coordinator: Mireia Fernández-Ardèvol (IN3-Open University of Catalonia)

Submitted in: July 2015

Accepted in: December 2015

Published in: January 2016
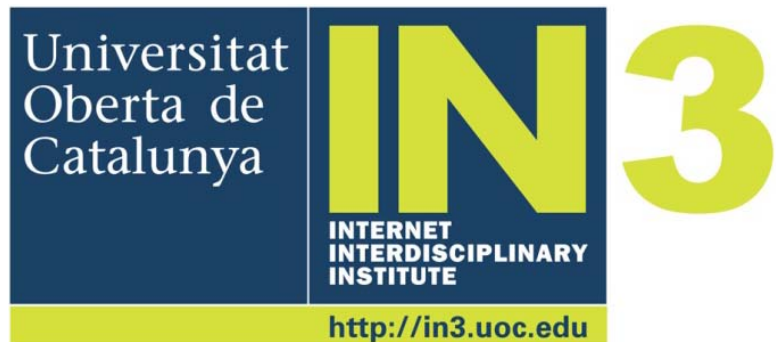


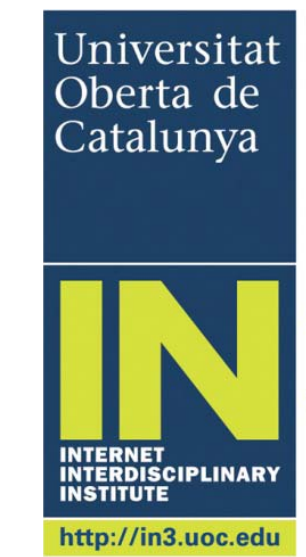

Internet Interdisciplinary Institute (IN3)

http://www.in3.uoc.edu

Parc Mediterrani de la Tecnologia

Av. Carl Friedrich Gauss, 5

08860 Castelldefels

Barcelona (Espanya)

Tel. 934505200

Universitat Oberta de Catalunya (UOC)

http://www.uoc.edu/

Av. Tibidabo, 39-43

08035 Barcelona

Espanya

Tel. 932532300

\section{(c)}

The texts published in this publication are - unless indicated otherwise - covered by the Creative Commons Spain Attribution-Non commercial-No derivative works 3.0 licence. You may copy, distribute, transmit and broadcast provided that you attribute it (authorship, publication name, publisher) in the manner specified by the author(s) or licensor(s).

The full text of the licence can be consulted here:

http://creativecommons.org/licenses/by-nc-nd/3.0/es/deed.en. 


\section{Table of contents}

Abstract

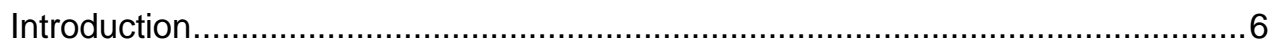

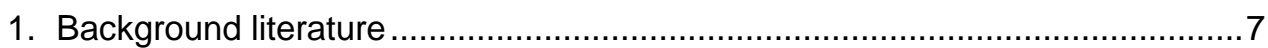

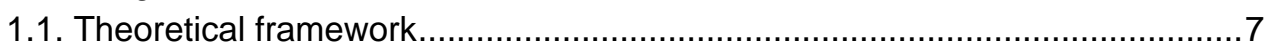

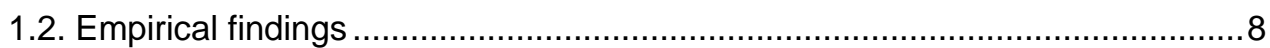

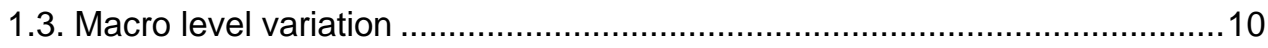

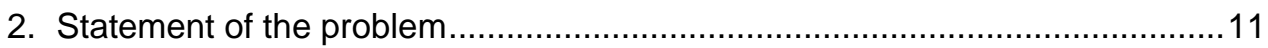

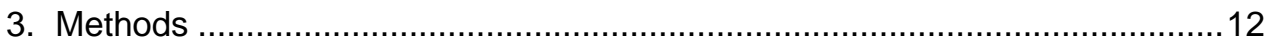

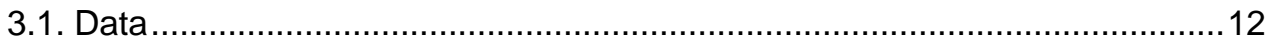

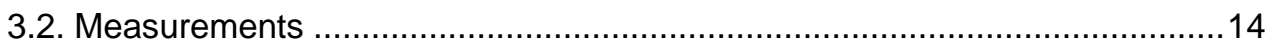

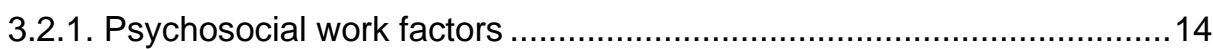

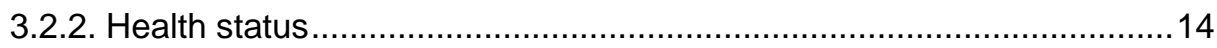

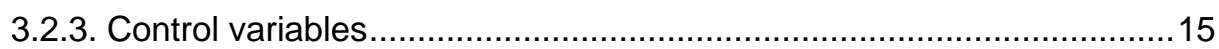

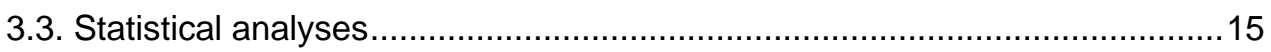

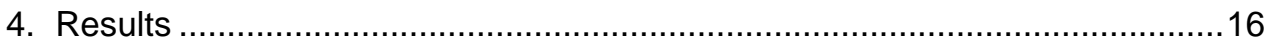

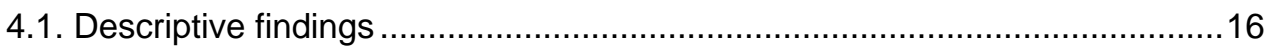

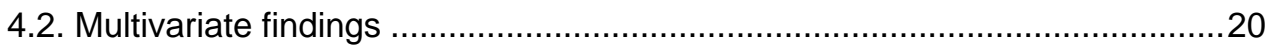

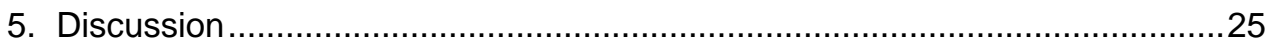

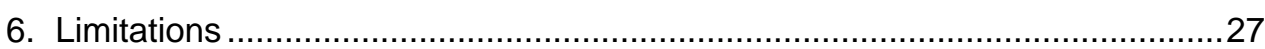

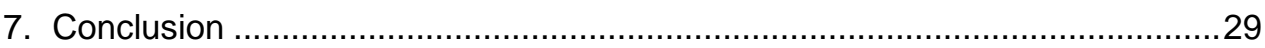

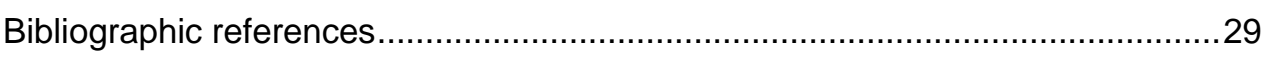

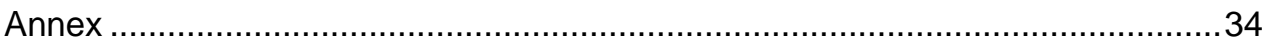




\title{
Psychosocial work factors and older workers' health in Europe
}

\author{
Daniel Blanche (dblanchet@uoc.edu) \\ Internet Interdisciplinary Institute (IN3) \\ Open University of Catalonia (UOC)
}

\author{
Recommended citation: \\ BLANCHE, Daniel (2016). "Psychosocial work factors and older workers' health in \\ Europe" [online working paper]. (Working Paper Series; WP15-003). IN3 Working Paper \\ Series. IN3 (UOC). [Accessed: dd/mm/yy]. \\ $<$ http://journals.uoc.edu/ojs/index.php/in3-working-paper-series/article/view/n15- \\ blanche/n15-blanche>
}

\begin{abstract}
Using data from 15 European countries from the Survey of Health, Ageing and Retirement in Europe (SHARE), we explore associations between several psychosocial work factors and self-perceived health among older workers (50 to 65 years old $(n=12,728)$. Drawing from the effort-reward imbalance and low control models, we hypothesise that (a) effort and reward factors are more relevant predictors of poor health reports than low control factors in Europe, and (b) that these associations are stronger in the less work-protective contexts of Eastern Europe and Mediterranean countries and weaker among the more protective Scandinavian and
\end{abstract}


Continental Western Europe contexts. After several logistic regression analyses, results showed that reward factors were the most relevant predictors in three out of four regions; and that Scandinavian and Continental Western Europe countries yield the strongest work stress-poor health association. These findings highlight the importance of promoting tailor-made labour and health policies that enable older workers remain longer in the labour market in view of the increasing ageing of the population.

\section{Keywords}

Older workers, Psychosocial work factors, Work stress, Self-rated health, Europe. 


\section{Introduction}

Much late attention has been given to the challenges of increasingly ageing rates of the population faced by the developed world, being the extension of labour force participation of older workers (women and men between 55 and 64 years old) one of the main policies designed to address this issue. Many European governments have addressed this issue by means of increasing the statutory age of retirement (Eurofound 2012a), as well as either impeding early retirement pathways or making it less financially viable (Eurofound 2012b, 2013). Concerns raised with demographic trends seem well grounded in the light of growing proportions of the population 65 years old and over in Europe, from 16.3 percent in 2010 to a projected 26.9 percent by 2050 . Likewise, a shrinking workforce is projected to become acute in the upcoming years where Europe would experience an increase from 24 older people for each 100 working-age individuals in 2010 up to 47 by 2050 (United Nations 2013). Although according to some scholars, the rise of life expectancy in the last decades has been one of the most salient signals of increasing quality of life in the developed world (Myck 2015), others question whether this rise is accompanied by decreases in unhealthy life years (Solé-Auró and Alcañiz 2015). Moreover, the expected remaining years of disability or illness-free at age 50 shows to vary greatly across European nations (Jagger et al., 2008), where countries such as Iceland or Norway present the best rates while countries like Latvia or Slovakia display the worst figures (Eurostat 2013).

It is acknowledged that the workplace is a key source affecting the health of the working-age population, wherein adequate employment and working conditions can provide, among others, protection from physical and psychosocial hazards (Commission on Social Determinants of Health 2008; Siegrist, Montano and Hoven 2014). While younger cohorts of workers report higher physically unpleasant working conditions, much of the health problems faced by workers from 50 years old on are often rooted in experiences of previous years reflecting an accumulated effect of exposures at work (Vendramin and Valenduc 2012). However, among older workers it is perhaps more important the exposure to psychological pressures causing stress. It has been observed that self-reported levels of stress at work increased in the last decades (Keese and OECD 2006), and that new disability benefit grants attributable to mental health problems increased in most OECD countries (OECD, 2010). In countries such as Denmark, Switzerland, or the United Kingdom, the proportion of workers between 50 and 64 years old receiving new disability grants due to mental ill-health surpassed those due to musculoskeletal disorders-around 32\%, 30\%, and $20 \%$ 
against $28 \%, 25 \%$, and $19 \%$ respectively for each kind of disability and country (OECD, 2010).

Psychosocial work risk is a concept widely used in occupational health research that captures the factors at the workplace that affect people's health status. Factors such as job content, work intensity, job autonomy, working time arrangements, social environment, job insecurity and career development are often included in analyses of psychosocial risk factors at work. Working conditions that allow the presence of such factors are key triggers of early retirement (Berg, Schuring, Avendano, Mackenbach and Burdorf 2010; Debrand and Lengagne 2008; Siegrist, Wahrendorf, Von Dem Knesebeck, Jürges, and Börsch-Supan 2007). Therefore, the preservation of older workers in good health shows to be crucial to fulfil the objectives of the European institutions regarding the extension of the working life as much as possible. Until this point, and to begin with this research paper, the following general question arises: How are psychosocial work factors related to poor health outcomes among the older workforce in Europe? The ambition of this study is to explore the links between these work stress related factors with unhealthy status of the older workforce in different European countries and regions.

\section{Background literature}

\subsection{Theoretical framework}

Psychosocial work environment is a concept that refers to the psychological and social aspects of the work milieu that exert an influence on the health of workers. Such influences include time pressure, reciprocity, repetitive tasks, control over one's own work, fairness, work demands, job security, social support by supervisors and colleagues, among many others (Eurofound and EU-OSHA 2014). It has become a prominent topic of research in occupational health and socioepidemiological studies in the last decades with enough potential to equate scholars' attention given to physical, chemical and biological risk factors. Among the broad corpus of literature generated on this issue, a handful of theoretical/conceptual frameworks stand out as the most predominant models used thus far. First, the "person-environment fit model" introduced by French et al. (1982) states a mismatch between two aspects in the workplace that may give rise to health problems among workers, which is the incongruence perceived between the person's skills and job demands, as well as between his or her job expectations and the supplies offered in the workplace. Second, Karasek and Theorell's (1990) influential "demand-control" model of job strain states that high 
psychological demands combined with low decision latitude may lead to psychological strain and physical diseases. The model has been supported by a relevant amount of empirical research, a fact that suggests that not only hazardous exposures to chemicals or undergoing physical strains are factors that deteriorate workers' health but also that the organization of work may affect negatively physical and mental health.

Third, Siegrist (1996) further develops these ideas and argues that experiencing an unbalanced distribution between a high investment of efforts and a low reception of rewards at work yields emotional distress due to the violation of reciprocity expectations. A stressful working environment comprises situations such as holding a demanding job, facing employment instability, investing high efforts, and lacking prospects of career advancements. Low rewards in the forms of status control, payment, and recognition, combined with high extrinsic-e.g., job demands-and intrinsic-e.g., need for control of challenging situation-efforts are likely to drive feelings of threat, anger, irritation, depression, or demoralization, which in turn may elicit sustained "autonomic arousal" (Siegrist 1996, p. 30). This influential model applies especially to social groups who suffer a growing segmentation of the labour market or exposed to structural unemployment and fast socioeconomic change, but also to groups participating in highly competitive career developments. Finally, an emergent alternative claims that the unbalance between efforts and rewards or control and workload does not suffice to account for psychosocial work factors on health status. Elovainio, Kivimäki and Vahtera (2002) bring forth an "organizational justice" model which calls attention to justice practiced within organizations in the forms of procedures-e.g., opportunities to appeal decisions, accuracy in the collection of information-and relations-e.g., biased treatment by supervisor, timely feedback, respect and consideration. Therefore, it is important to account both for low rewards and for the mechanisms used that determine the way in which they are allocated.

\subsection{Empirical findings}

Most of the literature on the work-related psychosocial risk factors has applied jointly the demand-control and effort-reward models. Such studies have revealed significant links to the development of a series of health issues: coronary heart disease, depressive symptoms, metabolic disorders, musculoskeletal problems, limited functioning, alcohol dependency, and asthma among the most frequently found (Siegrist et al. 2014). Nonetheless, how do these factors relate to older workers in particular? Depending on the psychosocial factor, the literature generally shows to be consistent and contradictory at times. Younger workers have reported higher social support from their supervisors and colleagues, as well as higher prospects for career promotion (Eurofound and EU-OSHA 2014; Eurofound 2012b). Research have found 
that younger workers express more needs of further training opportunities and that they perceive their job to be more unsecure (Eurofound and EU-OSHA 2014); yet, older workers feel comparatively more that their job does not involve learning new things, and those between 50 and 54 years old perceive higher job insecurity than any other age group (Eurofound 2012b). Conversely, it has been reported that older workers as a whole are less afraid of losing their job in the near future, but are less confident in finding a comparable job in case of forced or voluntary contract cessation (Eurofound and EU-OSHA 2014). Consistency has been found on older workers' more favourable factors such as better work-life balance, less irregular work schedules, lower intensity of work, greater latitude or autonomy, and satisfactory salary (Eurofound and EU-OSHA 2014; Eurofound 2012b), as well as fewer reports of workrelated injuries and infrequent illness absenteeism (Hoonakker and Duivenbooden 2010).

However, when taking into account the association with health outcomes, the picture is quite different. Jones, Latreille, Sloane and Staneva $(2011,2013)$ found that older workers were significantly more likely to report adverse work-related health risks such as perceived health risks, health complaints, mental and physical health, sickness absence, and fatigue compared to prime age workers (15-35 years old). Their data suggested that health was associated with an accumulation of work experiences, while work injuries were rather related to current risk exposures (see also Vendramin and Valenduc 2012). Prospective studies have suggested that sustained experience of adverse work stress—namely, low control, high effort and low reward-could translate into pronounced frailty (Kalousova and Mendes de Leon 2015), depressive symptoms (Lunau, Wahrendorf, Dragano and Siegrist 2013), and disabilities in the form of impairments or activity restrictions (Reinhardt, Wahrendorf and Siegrist 2013). There has also been found a social gradient in the experience of ill health as a function of occupational position (Siegrist et al. 2014). Different measures of occupational position-i.e., social class, social status, skill level—were associated to poorer quality of work, and a mediating effect of psychosocial risk factors between socioeconomic status and depressive symptoms (Hoven, Wahrendorf and Siegrist 2015) and retirement intentions (Wahrendorf, Dragano and Siegrist 2013) was found significant and particularly strong for lower occupational positions.

In this line, a strand of the literature examined the implications of work stress and health status in older workers' exit from paid employment. Low job control, defined as low ability of employees to influence decisions about their job and work organization (Gallie, 2011), was found to be a risk factor for disability pension, unemployment, and early retirement, a finding that entailed more labour market exit pathways compared to self-perceived health or unhealthy behaviours-i.e., high body mass index, physical inactivity, smoking history, and excessive alcohol intake (Robroek, Schuring, Croezen, Stattin and Burdorf 2013). Good working conditions and well-being have been found to delay retirement intentions in the near future (Siegrist et al. 2007), and were also found capable of extending older workers' participation in the labour market even when 
disabled or impaired (Pollak 2012). Siegrist and Wahrendorf (2011) found that continued employment after 60 years old was more prevalent among workers in good health and with perceived high job control, yet the association was weakened when controlling for country, suggesting that national contexts may affect the quality of work and chances of being employed after age 60. Additionally, quality of work was generally higher in countries with marked active labour market policies-particularly, lifelong learning-while extended employment into old age was more frequent in countries investing more in rehabilitation services-as for health care and labour reintegration are concerned.

\subsection{Macro level variation}

Contextual factors have an important say on the psychosocial work environment effects on the health of the working population. Certain macro-level characteristics are thought to represent protective resources against the risks of psychosocial factors at work through paths such as occupational safety legislation, dismissal protection laws, or minimum wage policies. Workplace protective factors such as union density and psychosocial safety climate were found to be more relevant for workers' self-perceived health than quality working conditions per se (Dollard and Neser 2013). Older workers in countries with low levels of active labour market policies, few rehabilitation services, low unemployment benefits, and high income inequality were found to be linked to higher depression risks in case of high effort-reward imbalance, meaning that favourable social and labour policies may buffer this pervasive effect (Lunau et al. 2013). The combination of high efforts and low rewards can be especially harmful under challenging macro-economic conditions, such as elevated unemployment, forced job mobility, and wage cutbacks. In this sense, similar patterns can be found among countries with parallel economic and socio-political settings as evidenced by the welfare state literature (for example, Arts and Gelissen 2002; Esping-Andersen 1990). Scandinavian countries have shown the lowest odds of depression among older workers due to effort-reward imbalance and low job control, contrary to the case of Liberal Anglo Saxon and Southern European countries who have shown higher depression risks in this population (Dragano, Siegrist and Wahrendorf 2011). The effect of psychosocial work stress is not confined to Western Europe. In Eastern European societies, the risk of experiencing poor subjective health was higher the higher the perceived effort-reward imbalance, yet low job control was not found to predict poor subjective health in the working population (Pikhart et al. 2001).

Welfare regimes have been frequently regarded as relevant determinants of employment related health, where countries with powerful trade unions and pro-labour parties tend to have universally oriented welfare policies that improve health standards 
in general (Benach et al. 2014). Employment relations arrangements are intrinsically related to welfare states as they are the product of social pacts that distribute the power relationships between organised labour, employers, and the state (Benach, Muntaner, Solar, Santana and Quinlan 2013). Countries with "de-commodification" welfare policies provide organised labour with a greater power to demand more protective arrangements in working conditions specifically and in working life more generally. In this line, and drawing from the industrial relations literature, contexts at the national level have been found to vary across Europe according to the following key features: union density, union fragmentation, employer association density, employer association fragmentation, collective bargaining coverage, centralisation of collective bargaining, and interaction of social partners with the state (Ebbinghaus 2006; European Commission 2008, 2013). Based on these indicators, authors and entities have discussed and utilised a typology representing the varying degrees of representative actors, institutionalised processes, and established practices present across the European Union member states (European Commission 2008, 2013; Gallie, 2011). Organised Corporatism regimes-e.g., Denmark, Sweden-enjoy high levels of union density, high collective bargaining coverage, high fragmentation of organisations, and high interaction of social partners with the state; whereas Social Partnership regimes-e.g., Germany, Netherlands-are quite like Organised Corporatist countries except for their medium level of union membership. State-Centred regimes-e.g., France, Italy - feature low union density, low centralisation of collective bargaining, low interaction with the state but higher state intervention; and Mixed or Transitional regimes-e.g., Estonia, Hungary-exhibit low organisational density, low and decentralised collective bargaining coverage, and a lack of interaction. All together, health effects of work stress tend to vary by type of welfare regime, and probably, by industrial relations regimes too.

\section{Statement of the problem}

A majority of studies analysing the association between work stress factors and health outcomes showed a greater consistency of the effort-reward imbalance model. The combination of high efforts and low rewards seemed to exert greater influence than the control dimension on its own. However influential Siegrist's model might be across multiple empirical studies, it is surprising not to find research testing the links between the components of its dimensions separately and the health condition of older workers. As shown previously, older workers represent a more vulnerable segment of the working population due to accumulative exposures to work environments that are found to be detrimental for their health, yet apparently there lacks a detailed 
explanation accounting for the different properties the effort-reward and demandcontrol models enclose. Moreover, it is common to find studies that conceptualized each model in different ways-e.g., taking work intensity or social support as separate notions from psychosocial work risks-as well as the issue of the potential overlapping nature of some of its indicators-e.g., recognition at work and social support by supervisors may not always be interpreted as different things. Therefore: What concrete psychosocial factors related to work are associated with the health status of older workers (50-65 years old) in Europe? Based on the literature review, we expect to find a greater prominence of effort and reward factors compared to low job control variables associated with older workers' poor health among countries and regimes (hypothesis 1).

Likewise, the literature review evidenced a general cross-national comparative approach accounting for differences between countries individually. Although a classic and desirable approach, none of the consulted studies-with the sole exception of Dragano et al. (2011)_engaged in comparisons between regimes or regions in an explicit manner. Distinct patterns may arise from regime comparisons that may shed light over the particular psychosocial work factors present when older worker's health is poor in each region. In this sense: Which are the relevant work stress factors associated with older workers' health in the different European regimes? According to the review, there is a close similarity between welfare states and industrial or employment relations regimes where Scandinavian countries are more protective contexts for the labour environment, whereas Eastern and Southern European countries are less so. In this line, we expect the work stress-poor health relation among older workers to be stronger in Mixed or Transitional and State-Centred regimes, and weaker in Social Partnership and Organised Corporatism regimes (hypothesis 2).

\section{Methods}

\subsection{Data}

Data were obtained from a longitudinal ageing study, the Survey of Health, Aging, and Retirement in Europe in its fourth round, with information of 16 continental countries (SHARE, Wave 4, Release 1.1.1) (Börsch-Supan 2013). Countries included were Austria, Belgium, Czech Republic, Denmark, Estonia, France, Germany, Hungary, Italy, Netherlands, Poland, Portugal, Slovenia, Spain, Sweden, and Switzerland. The survey has been designed to represent the population 50 years old or over and it has collected sociological, economical, and health information through 
several thematic modules-e.g., activities, employment, social networks, consumption patterns, behavioural risks, finances, among others. The fourth wave gathered information across participant countries between late 2010 and early 2012 with a prominent amount of respondents throughout 2011. The sample of analysis was restricted to older women and men between 50 and 65 years old (both values included) - 30,272 observations (51.76\%) - who were engaged in paid employment at the moment of the interview-14,143 observations (46.72\%). Older people out of the labour market could not be included in the analysis because the battery of psychosocial work factors was filtered only to those in paid work. Also, Switzerland was discarded from the analyses because it was not explicitly addressed in the literature revised on industrial relations regimes in Europe. The final sample size was of 12,728 respondents, and distributed by employment relations regimes as follows: Organised Corporatism $(n=1,392)$, Social Partnership $(n=4,065)$, State-Centred $(n=$ $3,177)$, and Mixed or Transitional $(n=4,094)$ (see Figure 1). Details of the survey are provided by the authors and coordinators of the project (see Börsch-Supan et al. 2013; Malter and Börsch-Supan 2013).

Figure 1. Map of countries by Industrial Relations Regimes

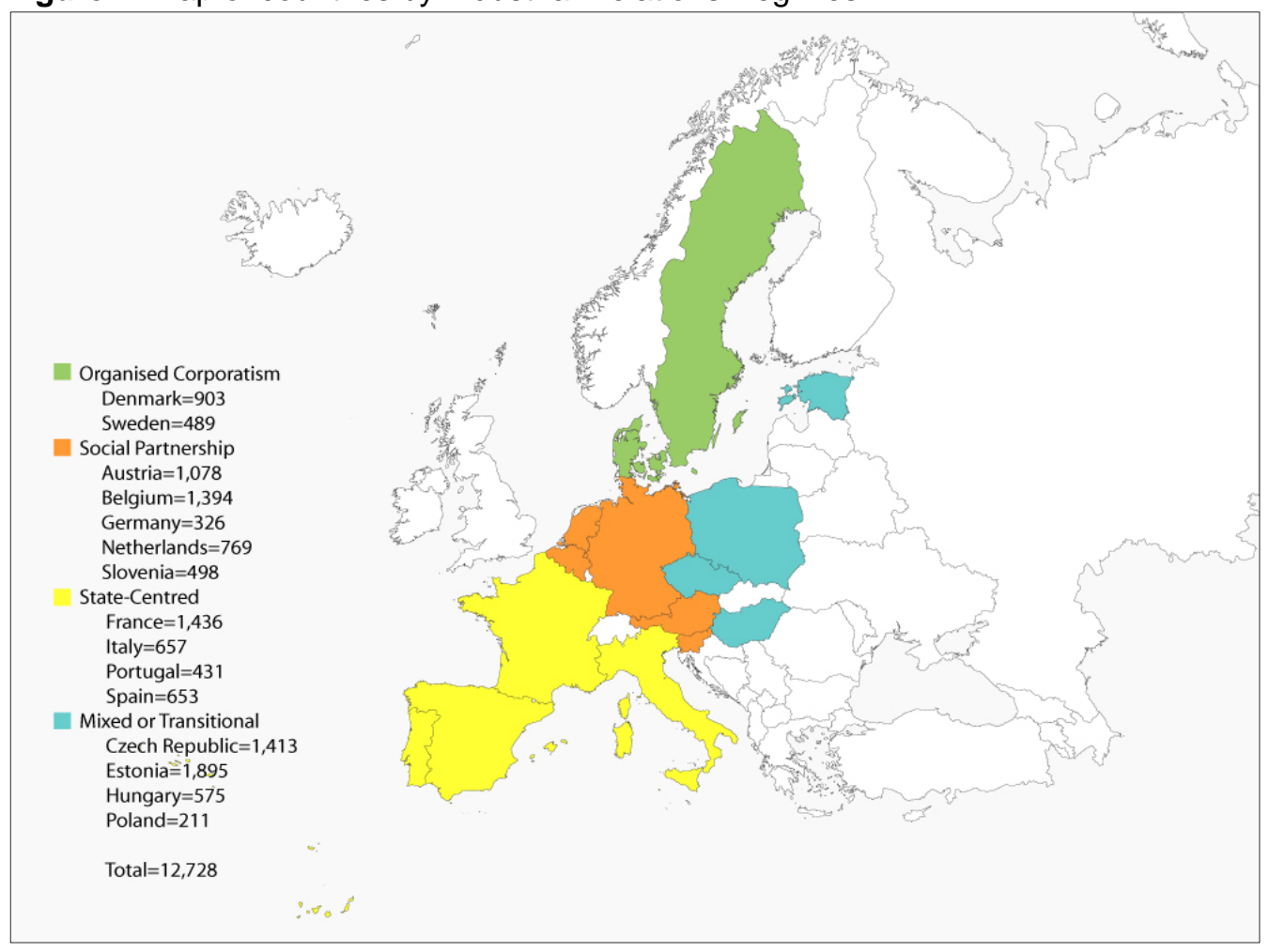

Source: Own elaboration based on Survey of Health, Ageing and Retirement in Europe (SHARE) Wave 4. Figures are sample sizes $(n)$. 


\subsection{Measurements}

\subsubsection{Psychosocial work factors}

SHARE used a short version of validated scales of work stress indicators; yet it included a battery of questions with the core indicators for each dimension of the conceptual models. Concerning the demand-control model, only those belonging to the control side were included in the survey. Low control was measured with the respondent's perception of degree of autonomy in the job and the availability of opportunities in the workplace to develop new skills. However, as performed in previous research by some scholars (Kalousova and Mendes de Leon 2015; Pollak 2012), we classified the perception of receiving social support in difficult situations as belonging to the control dimension.

The effort dimension included two indicators: perception of the job being physically demanding and experiencing time pressure due to a heavy workload. The reward dimension comprised four variables, which were receiving recognition for the work done, perception of adequacy of salary, job promotion possibilities, and job security. All variables were measured with Likert-scale items which we dichotomised 1 if the respondent perceived the work-related variable in a detrimental way (reverse coding was needed in some cases), and 0 if perceived positively. A summary of the work risk factors by dimensions as well as the wording of the questions are provided in the Annex section.

\subsubsection{Health status}

Self-perceived health is a subjective measure of the overall health condition of the respondent. Despite its subjective nature, several studies have documented its satisfactory correlation with more "objective" measures of health. It is found that bad self-rated health is strongly associated to mortality and morbidity rates even after controlling for other health indicators and covariates (Idler and Benyamini 1997). It has been indicated that poor self-assessed health may be a feature that captures different adverse psychosocial states such as social isolation, negative life events, depressive episodes, and work stress. Research has shown that self-rated health varies according to socioeconomic and psychosocial conditions, such as level of social support, or degree of control in life (Pikhart et al. 2001). Therefore, this indicator is a simple and direct way of measuring perceptions of health considering aspects that can be as broad and inclusive as the person chooses to. In the survey used, respondents were asked: "Would you say your health is...", choosing between excellent, very good, good, fair, and poor. We defined a dichotomous version of this variable where 1 gathered 
poor evaluations of health (fair to poor) and 0 represented good health assessments (excellent to good).

\subsubsection{Control variables}

Age, sex, marital status, education, and annual net income from employment were included as the core control variables. Age, education (in years), and income were treated as continuous variables-the latter was log transformed. Sex was coded 0 if the respondent was male and 1 if female. Marital status was dichotomised 1 if the respondent was living together with her or his spouse/registered partner, and 0 represented the rest of categories-i.e., married but living separately from spouse, single, divorced, or widowed. In different steps, countries were added also as control variables either individually or nested in the typology implemented (employment relations regimes).

\subsection{Statistical analyses}

Regular descriptive analyses were conducted to observe the distribution of the variables across countries and regimes. Table 1 contains the distribution of all variables used in overall terms as well as detailed by country. Subsequently, all psychosocial work items were tested for potential multicollinearity, which yielded weak correlation coefficients except for recognition and social support in the Eastern Europe group (<.46). This was probably due to a conceptual similarity interpreted in this group of countries; yet they were kept separately to allow comparability between regimes. Further, logistic regression analyses-reporting odds ratios and 95\% confidence intervals-were carried out in several steps using sampling weights. First, a full model was tested with pooled data controlling for employment relations regimes to observe the behaviour of these groups regarding the dependent variable in presence of all the variables of interest. Second, the full model was again tested with pooled data, only now controlling for each country individually to observe differences among the variables between the two models. Lastly, full models were tested by industrial relations regimes separately to observe associations within regimes and to enable comparisons between them. The constant was omitted in all models in order to display the direct coefficients of the variables. All calculations were done using Stata 13. 


\section{Results}

\subsection{Descriptive findings}

A great majority of respondents-over three out of four-across these European nations perceived their health as good, albeit a closer look by countries revealed great variability in this respect. A first look suggests that Organised Corporatism countries exhibited comparatively low levels of self-perceived poor health, whereas Mixed or Transitional ones showed some of the highest poor health levels-in all four countries it exceeded 20 percent of cases. The other two regimes showed more variability, presenting cases with relatively low and high levels of poor health, such as Austria (12 percent) and Germany (29 percent) for the Social Partnership group and Italy (13 percent) and Portugal (42 percent) for the State-Centred group. Estonia, Portugal, Hungary and Germany showed the highest proportions of reported bad health; whilst Denmark, Austria and Italy, the highest proportions of good health. Work stress variables belonging to the effort dimension-i.e., job physically demanding and heavy workload-showed the highest average proportion overall, and the control dimension variables-i.e., job latitude, new skills opportunities, and social support-the lowest in average. However, the reward variables presented the largest variability, with 21 percent reporting poor job security and 68 percent reporting poor prospects for career advancements. The former partially followed patterns described in the literature, and the latter was somewhat expected since the older people grow, the more likely the chances of staying in the same position until the time to retire arrives. In fact, in nearly all countries, experiencing poor career prospects was the highest reported work stress factor; while experiencing job insecurity was the lowest reported work stress factor in six countries, and the lack of receiving social support was the least reported issue in four of them.

Age of respondents was approximately 56 years old in general, where mean ages across countries ranged between 54 and 58 years old. In almost all countries there was a higher presence of males in paid labour, somewhat expected for these cohorts; excepting for Estonia and France, with a marked sex difference in the former and slight in the latter. A great majority of respondents shared the same dwelling with their spouse or registered partner, yet Estonia showed the highest proportion not belonging to this category (41 percent). The average years of education of this population was of nearly 13 years, with Germany having the most educated older workers among these countries (14 years) and Portugal having the least (approximately 8 years). As for annual net income from employment, older workers in Denmark received the highest average amounts, whereas the relative lowest average remuneration was among older workers in Hungary. 
Psychosocial work factors and older workers' health in Europe

(a) Daniel Blanche

Table 1. Distribution of measures among older workers (50-65 years old) active in the labour market (percentages/means)

\begin{tabular}{|c|c|c|c|c|c|c|}
\hline & $\begin{array}{r}\text { All } \\
\text { countries }\end{array}$ & Denmark & Sweden & Austria & Belgium & Germany \\
\hline \multicolumn{7}{|l|}{ Self-rated health } \\
\hline Good & 77.62 & 89.61 & 84.84 & 88.00 & 86.52 & 70.55 \\
\hline Poor & 22.38 & 10.39 & 15.16 & 12.00 & 13.48 & 29.45 \\
\hline \multicolumn{7}{|l|}{ Psychosocial work factors } \\
\hline Job physically demanding & 49.14 & 36.07 & 37.42 & 52.23 & 38.52 & 49.33 \\
\hline Heavy workload & 47.27 & 45.84 & 42.53 & 54.73 & 49.92 & 50.74 \\
\hline Low job latitude & 28.09 & 16.36 & 15.44 & 37.47 & 27.00 & 24.93 \\
\hline No opportunity to develop new skills & 34.08 & 15.34 & 20.83 & 27.8 & 33.05 & 31.79 \\
\hline No support in difficult situations & 27.83 & 16.16 & 20.18 & 25.65 & 32.68 & 22.36 \\
\hline No recognition for work done & 30.97 & 15.5 & 18.47 & 27.36 & 29.64 & 24.28 \\
\hline Salary inadequate & 47.08 & 26.87 & 44.76 & 31.95 & 33.94 & 43.72 \\
\hline Poor job prospects & 67.80 & 69.46 & 78.54 & 51.18 & 46.72 & 71.58 \\
\hline Poor job security & 21.30 & 20.32 & 12.92 & 9.07 & 14.18 & 11.72 \\
\hline Age & 56.15 & 56.54 & 58.49 & 55.04 & 55.35 & 57.41 \\
\hline \multicolumn{7}{|l|}{ Sex } \\
\hline Female & 45.71 & 47.54 & 47.63 & 44.10 & 46.93 & 49.48 \\
\hline Male & 54.29 & 52.46 & 52.37 & 55.90 & 53.07 & 50.52 \\
\hline \multicolumn{7}{|l|}{ Marital status } \\
\hline Living with spouse/partner & 76.49 & 74.29 & 74.68 & 67.04 & 68.42 & 73.71 \\
\hline Others & 23.51 & 25.71 & 25.32 & 32.96 & 31.58 & 26.29 \\
\hline Years of education & 12.57 & 10.83 & 13.24 & 9.52 & 13.50 & 14.13 \\
\hline Income (log) & 9.35 & 10.10 & 9.92 & 9.69 & 9.82 & 9.17 \\
\hline$n$ & 12,728 & 903 & 489 & 1,078 & 1,394 & 326 \\
\hline
\end{tabular}

Source: Own elaboration based on the Survey of Health, Ageing and Retirement in Europe (SHARE) Wave 4. Weighted data. Figures are percentages; italic figures are means. 
Psychosocial work factors and older workers' health in Europe @) Daniel Blanche

Table 1 (continued). Distribution of measures among older workers (50-65 years old) active in the labour market (percentages/means)

\begin{tabular}{|c|c|c|c|c|c|}
\hline & Netherlands & Slovenia & France & Italy & Portugal \\
\hline \multicolumn{6}{|l|}{ Self-rated health } \\
\hline Good & 81.59 & 77.75 & 80.27 & 87.09 & 57.63 \\
\hline Poor & 18.41 & 22.25 & 19.73 & 12.91 & 42.37 \\
\hline \multicolumn{6}{|l|}{ Psychosocial work factors } \\
\hline Job physically demanding & 37.89 & 42.07 & 45.96 & 55.16 & 68.47 \\
\hline Heavy workload & 34.11 & 52.40 & 41.09 & 52.80 & 49.08 \\
\hline Low job latitude & 16.09 & 27.56 & 22.61 & 37.72 & 28.62 \\
\hline No opportunity to develop new skills & 17.87 & 25.93 & 40.02 & 38.75 & 17.96 \\
\hline No support in difficult situations & 18.74 & 23.14 & 36.22 & 40.29 & 26.35 \\
\hline No recognition for work done & 23.02 & 43.33 & 40.19 & 38.62 & 32.42 \\
\hline Salary inadequate & 30.84 & 49.40 & 51.22 & 47.40 & 43.7 \\
\hline Poor job prospects & 59.63 & 60.19 & 61.32 & 68.21 & 75.88 \\
\hline Poor job security & 33.80 & 28.59 & 14.16 & 22.61 & 42.82 \\
\hline Age & 57.22 & 54.20 & 55.18 & 54.96 & 55.53 \\
\hline \multicolumn{6}{|l|}{ Sex } \\
\hline Female & 45.58 & 39.67 & 50.24 & 36.21 & 49.58 \\
\hline Male & 54.42 & 60.33 & 49.76 & 63.79 & 50.42 \\
\hline \multicolumn{6}{|l|}{ Marital status } \\
\hline Living with spouse/partner & 78.13 & 76.99 & 71.49 & 86.87 & 86.13 \\
\hline Others & 21.87 & 23.01 & 28.51 & 13.13 & 13.87 \\
\hline Years of education & 13.12 & 12.40 & 12.78 & 11.67 & 8.48 \\
\hline Income (log) & 9.91 & 9.06 & 9.82 & 9.47 & 9.03 \\
\hline \multirow[t]{2}{*}{$n$} & 769 & 498 & 1,436 & 657 & 431 \\
\hline & & & & & (continued) \\
\hline
\end{tabular}

Source: Own elaboration based on the Survey of Health, Ageing and Retirement in Europe (SHARE) Wave 4. Weighted data. Figures are percentages; italic figures are means. 
Psychosocial work factors and older workers' health in Europe @) Daniel Blanche

Table 1 (continued). Distribution of measures among older workers (50-65 years old) active in the labour market (percentages/means)

\begin{tabular}{|c|c|c|c|c|c|}
\hline & Spain & Czech Rep. & Estonia & Hungary & Poland \\
\hline \multicolumn{6}{|l|}{ Self-rated health } \\
\hline Good & 77.32 & 78.05 & 52.54 & 62.36 & 72.41 \\
\hline Poor & 22.68 & 21.95 & 47.46 & 37.64 & 27.59 \\
\hline \multicolumn{6}{|l|}{ Psychosocial work factors } \\
\hline Job physically demanding & 46.95 & 49.3 & 57.66 & 50.48 & 64.09 \\
\hline Heavy workload & 48.08 & 51.08 & 25.31 & 49.44 & 44.72 \\
\hline Low job latitude & 28.02 & 39.32 & 29.76 & 41.31 & 44.25 \\
\hline No opportunity to develop new skills & 37.23 & 28.82 & 29.49 & 42.73 & 48.22 \\
\hline No support in difficult situations & 17.23 & 32.46 & 19.81 & 20.57 & 31.60 \\
\hline No recognition for work done & 27.22 & 41.02 & 38.21 & 55.85 & 27.33 \\
\hline Salary inadequate & 54.98 & 51.01 & 65.22 & 69.17 & 59.57 \\
\hline Poor job prospects & 67.17 & 78.26 & 69.23 & 70.70 & 75.45 \\
\hline Poor job security & 29.39 & 41.33 & 37.08 & 44.86 & 41.29 \\
\hline Age & 55.53 & 55.14 & 56.11 & 55.34 & 56.73 \\
\hline \multicolumn{6}{|l|}{ Sex } \\
\hline Female & 40.92 & 45.38 & 57.18 & 47.21 & 43.17 \\
\hline Male & 59.08 & 54.62 & 42.82 & 52.79 & 56.83 \\
\hline \multicolumn{6}{|l|}{ Marital status } \\
\hline Living with spouse/partner & 79.25 & 73.49 & 58.95 & 76.15 & 79.67 \\
\hline Others & 20.75 & 26.51 & 41.05 & 23.85 & 20.33 \\
\hline Years of education & 11.05 & 13.06 & 13.07 & 11.99 & 11.67 \\
\hline Income (log) & 9.26 & 8.65 & 8.01 & 7.71 & 8.00 \\
\hline$n$ & 653 & 1,413 & 1,895 & 575 & 211 \\
\hline
\end{tabular}

Source: Own elaboration based on the Survey of Health, Ageing and Retirement in Europe (SHARE) Wave 4. Weighted data. Figures are percentages; italic figures are means. 
To this point, and recapping the research questions: To what extent can the distribution of poor self-rated health in each industrial relations regime be attributable to work stress factors? To examine the answer, we follow up with the results of the multivariate analyses.

\subsection{Multivariate findings}

In Table 2, results of the first logistic regression models are presented. In the first model (I), all variables were taken into account and controlled for industrial relations regimes. We observe that among all psychosocial work factors predicting poor self-rated health in the older workers' population, only job insecurity was found to hold a significant association. The estimation indicated that in all countries included, those who perceived insecurity in the job position had 44 percent higher odds of perceiving their health as poor. This contrasts with the descriptive results since job insecurity registered one of the lowest records among all work stress factors. The model also showed that the higher the years of education and annual net income from employment, the lower the odds of feelings of bad health. This provides hints of the protective nature of factors related to higher socioeconomic conditions among the older workforce. As for the industrial relations regimes, no significant effects on poor selfperceived health were registered in any of the levels of this variable. The second model (II) shows the results of the full model controlled by all countries included in the sample. Similar results yielded from this model with respect to the previous one. Perceived job insecurity showed to be a slightly stronger predictor of poor health when disaggregating countries: 48 percent higher the odds. The fact that countries analysed in a disaggregated manner strengthened the association between job insecurity and poor self-rated health may imply a within heterogeneous nature of the regimes at issue. The association between number of years of education and poor self-rated health was slightly stronger in this model, whereas income no longer remained significant. In addition, being male appeared to be somewhat strongly associated with poor health among the older workforce: 39 percent more odds compared to women. Countries introduced individually did not seem to yield any significant results in predicting poor self-rated health. However, the model increased slightly its predictive power compared to the first model. This increase may suggest that by accounting for the variability represented by each country, the predictive power of work stress factor along with other independent variables was enhanced. Table 1 showed an important variability in the distribution of the variables used across countries and members of the same industrial relations regime. While this first step in the multivariate stage suggests a better fit when countries were introduced individually, the next step takes into account this result and involves within-regime analyses controlling for its members. 
Table 2. Logistic regression for poor self-perceived health among older workers (50-65 years old) active in the labour market (odds ratios and 95\% confidence intervals)

\begin{tabular}{|c|c|c|}
\hline & Regimes (I) & Countries (II) \\
\hline \multicolumn{3}{|l|}{ Psychosocial work factors } \\
\hline Job physically demanding & $0.95[0.67,1.34]$ & $0.93[0.66,1.31]$ \\
\hline Heavy workload & $1.25[0.90,1.75]$ & $1.25[0.89,1.75]$ \\
\hline Low job latitude & $1.04[0.72,1.52]$ & $1.08[0.74,1.58]$ \\
\hline No chances to develop new skills & $1.28[0.88,1.88]$ & $1.25[0.85,1.84]$ \\
\hline No support in difficult situations & $1.28[0.89,1.82]$ & $1.37[0.95,1.97]$ \\
\hline No recognition for work done & $0.91[0.65,1.28]$ & $0.93[0.66,1.32]$ \\
\hline Salary inadequate & $1.25[0.90,1.73]$ & $1.18[0.84,1.65]$ \\
\hline Poor job prospects & $1.34[0.93,1.92]$ & $1.26[0.88,1.81]$ \\
\hline Poor job security & $1.44[1.03,2.02]^{*}$ & $1.48[1.05,2.09]^{*}$ \\
\hline Age & $1.04[0.99,1.08]$ & $1.02[0.98,1.07]$ \\
\hline \multicolumn{3}{|c|}{ 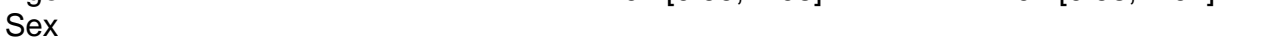 } \\
\hline Male (ref.) & 1 & 1 \\
\hline Female & $0.74[0.54,1.01]$ & $0.71[0.52,0.99]^{*}$ \\
\hline \multicolumn{3}{|l|}{ Marital status } \\
\hline Others (ref.) & 1 & 1 \\
\hline Living with spouse/partner & $1.19[0.84,1.71]$ & $1.22[0.83,1.77]$ \\
\hline Years of education & $0.94[0.91,0.98]^{\star *}$ & $0.92[0.89,0.96]^{\star * *}$ \\
\hline Income (log) & $0.86[0.76,0.97]^{*}$ & $0.88[0.77,1.01]$ \\
\hline \multicolumn{3}{|l|}{ Regimes } \\
\hline Organised Corporatism & $0.10[0.01,1.75]$ & \\
\hline Social Partnership & $0.26[0.02,4.61]$ & \\
\hline State-Centred & $0.14[0.01,2.15]$ & \\
\hline Mixed or Transitional & $0.19[0.01,2.81]$ & \\
\hline \multicolumn{3}{|l|}{ Countries } \\
\hline Denmark & & $0.13[0.01,2.56]$ \\
\hline Sweden & & $0.20[0.01,4.67]$ \\
\hline Austria & & $0.14[0.01,2.60]$ \\
\hline Belgium & & $0.22[0.01,4.27]$ \\
\hline Germany & & $0.58[0.03,13.15]$ \\
\hline Netherlands & & $0.30[0.01,6.33]$ \\
\hline Slovenia & & $0.28[0.02,4.97]$ \\
\hline France & & $0.26[0.01,5.04]$ \\
\hline Italy & & $0.15[0.01,2.92]$ \\
\hline Portugal & & $0.46[0.02,8.71]$ \\
\hline Spain & & $0.30[0.02,5.71]$ \\
\hline Czech Republic & & $0.24[0.01,4.32]$ \\
\hline Estonia & & $1.02[0.05,18.77]$ \\
\hline Hungary & & $0.60[0.03,10.84]$ \\
\hline Poland & & $0.28[0.01,5.50]$ \\
\hline$n$ & 8,231 & 8,231 \\
\hline Pseudo $R^{2}$ & $0.06^{* * *}$ & $0.08^{* * *}$ \\
\hline
\end{tabular}

Source: Own elaboration based on the Survey of Health, Ageing and Retirement in Europe (SHARE) Wave 4. Weighted data. Estimates significant at the following levels are in boldface: ${ }^{\star} p<.05,{ }^{\star \star} p<.01,{ }^{\star \star \star} p<.001$. 
The full model was analysed next by industrial relations regimes to examine what were the work stress factors associated with poor health in each one of them (see Table 3). First, we see that in the Organised Corporatism regime, poor job latitude or autonomy was strongly and significantly related to reported bad health-130 percent more odds than good job latitude. This variable, belonging to the control dimension, was the only significant predictor of all psychosocial work factors for this group. Living with spouse or partner was somewhat strongly associated with experiencing poor health, and years of education also showed a significant although weaker association. As for the member countries, neither residing in Denmark nor in Sweden appeared to exert a significant contribution to the model, although noteworthy is the wide confidence intervals in both cases, which suggest that country of residence enclosed little knowledge about the effect on poor health. Likewise, it could reflect a small sample size in each case. Second, in the Social Partnership group, poor job security was the only work stress factor associated with perceived bad health in terms of 152 percent more odds, which was a significant and even stronger figure than the work stress predictor in the Organised Corporatism group. Being male was also strongly associated with perceived bad health, with odds higher than 50 percent compared to women. Country of residence did not report any significant results either, although in this case the confidence intervals widened notoriously. This could reflect the presence of relatively small sample sizes, particularly for Germany-326 observations.

Turning to the State-Centred regime, another reward variable was significantly linked to poor self-rated health. Perceiving salaries as being inadequate considering all efforts done in the job showed to be a health risk factor by 50 percent higher odds than those who felt satisfied with their remuneration. Age was significantly associated in the sense that as older workers get older, the risk of rating their health poorly raised. Socioeconomic factors, such as years of education and annual net income, displayed a significant association with bad health at relatively similar strength levels: the higher the years in education and income, the lower the odds of experiencing bad health. Contrarily to the previous regimes, residing in a country-i.e., Italy-appeared to be significantly associated with reporting good health among the older workforce. Italy showed one of the highest levels of reported good health in Table 1, which now reflected an association with this variable. Yet, all other countries in the group presented no such significant odds. Finally, low perceived job security significantly predicted poor subjective health in the Mixed or Transitional countries, by 86 percent higher the odds of suffering such status. Age also seemed to be associated with bad health perception in terms of the older the people were; yet, no other sociodemographic factors seemed to relate to poor subjective health. Countries seemed to be strongly and significantly related to good health reports in all four countries. This contrasts with distributions in Table 1 which showed relatively high prevalence of reported poor health among its member countries compared to the rest. 
Table 3. Logistic regression for poor self-perceived health among older workers (50-65 years old) active in the labour market by Industrial Relations Regimes (odds ratios and 95\% confidence intervals)

\begin{tabular}{|c|c|c|}
\hline & $\begin{array}{l}\text { Organised } \\
\text { Corporatism (III) }\end{array}$ & $\begin{array}{l}\text { Social Partnership } \\
\text { (IV) }\end{array}$ \\
\hline \multicolumn{3}{|l|}{ Psychosocial work factors } \\
\hline Job physically demanding & $0.85[0.49,1.43]$ & $1.16[0.62,2.18]$ \\
\hline Heavy workload & $0.61[0.35,1.07]$ & $1.27[0.68,2.37]$ \\
\hline Low job latitude & $2.30[1.08,4.89]^{*}$ & $1.25[0.59,2.64]$ \\
\hline No chances to develop new skills & $1.59[0.87,2.89]$ & $1.22[0.61,2.47]$ \\
\hline No support in difficult situations & $1.49[0.81,2.73]$ & $1.22[0.57,2.58]$ \\
\hline No recognition for work done & $1.34[0.74,2.45]$ & $0.90[0.41,1.98]$ \\
\hline Salary inadequate & $1.50[0.85,2.65]$ & $0.92[0.46,1.83]$ \\
\hline Poor job prospects & $0.64[0.33,1.24]$ & $1.17[0.60,2.25]$ \\
\hline Poor job security & $1.17[0.60,2.29]$ & $2.52[1.14,5.57]^{*}$ \\
\hline Age & $0.99[0.92,1.06]$ & $0.95[0.86,1.05]$ \\
\hline \multicolumn{3}{|c|}{ 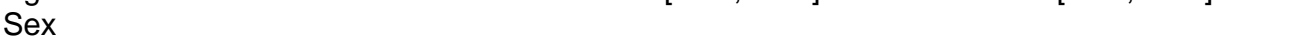 } \\
\hline Male (ref.) & 1 & 1 \\
\hline Female & $1.25[0.72,2.16]$ & $0.47[0.26,0.86]^{*}$ \\
\hline \multicolumn{3}{|l|}{ Marital status } \\
\hline Others (ref.) & 1 & 1 \\
\hline Living with spouse/partner & $0.55[0.31,0.97]^{*}$ & $1.98[0.94,4.18]$ \\
\hline Years of education & $0.95[0.91,1.00]^{*}$ & $0.94[0.87,1.02]$ \\
\hline Income (log) & $0.94[0.77,1.13]$ & $0.86[0.70,1.06]$ \\
\hline \multicolumn{3}{|l|}{ Countries } \\
\hline Denmark & $0.97[0.01,103.86]$ & \\
\hline Sweden & $1.55[0.01,227.32]$ & \\
\hline Austria & & $8.00[0.02,3570.90]$ \\
\hline Belgium & & $12.24[0.03,5816.12]$ \\
\hline Germany & & $\begin{array}{l}37.29 \\
{[0.06,24835.94]}\end{array}$ \\
\hline Netherlands & & $16.52[0.03,9893.23]$ \\
\hline Slovenia & & $12.30[0.03,5368.15]$ \\
\hline$n$ & 1,157 & 2,577 \\
\hline \multirow[t]{2}{*}{ Pseudo $R^{2}$} & $0.09 * * *$ & $0.11^{* * *}$ \\
\hline & & (continued) \\
\hline
\end{tabular}

Source: Own elaboration based on the Survey of Health, Ageing and Retirement in Europe (SHARE) Wave 4. Weighted data. Estimates significant at the following levels are in boldface: ${ }^{\star} p<.05,{ }^{* \star} p<.01,{ }^{\star \star *} p<.001$.

In sum, on the one hand, these results give partial support to the first hypothesis. In three out of four industrial relations regimes, psychosocial work factors related to the effort and reward dimensions were significantly linked to subjective poor health among the older workforce-concretely, job insecurity and inadequate salary-yet in the Organised Corporatism regime, the factor predicting poor self-rated health was poor job latitude, a variable from the control dimension. On the other hand, analyses 
Table 3 (continued). Logistic regression for poor self-perceived health among older workers (50-65 years old) active in the labour market by industrial relations regime (odds ratios and $95 \%$ confidence intervals)

\begin{tabular}{|c|c|c|}
\hline & State-Centred (V) & $\begin{array}{l}\text { Mixed or Transitional } \\
(\mathrm{VI})\end{array}$ \\
\hline \multicolumn{3}{|l|}{ Psychosocial work factors } \\
\hline Job physically demanding & $0.88[0.61,1.27]$ & $0.70[0.41,1.20]$ \\
\hline Heavy workload & $1.09[0.73,1.62]$ & $1.64[0.96,2.80]$ \\
\hline Low job latitude & $0.98[0.66,1.46]$ & $0.69[0.42,1.15]$ \\
\hline No chances to develop new skills & $1.15[0.75,1.76]$ & $1.64[0.97,2.78]$ \\
\hline No support in difficult situations & $1.37[0.88,2.14]$ & $1.63[0.89,3.00]$ \\
\hline No recognition for work done & $0.86[0.59,1.26]$ & $1.51[0.84,2.70]$ \\
\hline Salary inadequate & $1.50[1.05,2.14]^{\star}$ & $1.09[0.59,2.02]$ \\
\hline Poor job prospects & $1.28[0.87,1.88]$ & $1.65[0.83,3.28]$ \\
\hline Poor job security & $0.96[0.64,1.44]$ & $1.86[1.14,3.06]^{\star *}$ \\
\hline Age & $1.06[1.01,1.11]^{\star *}$ & $1.21[1.12,1.31]^{\star \star \star}$ \\
\hline \multicolumn{3}{|r|}{ 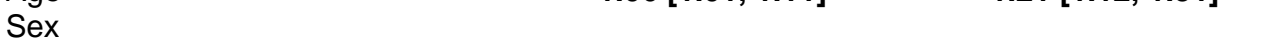 } \\
\hline Male (ref.) & 1 & 1 \\
\hline Female & $1.01[0.69,1.48]$ & $0.85[0.51,1.42]$ \\
\hline \multicolumn{3}{|l|}{ Marital status } \\
\hline Others (ref.) & 1 & 1 \\
\hline Living with spouse/partner & $0.72[0.45,1.14]$ & $1.40[0.77,2.55]$ \\
\hline Years of education & $0.91[0.87,0.95]^{\star \star \star}$ & $0.92[0.81,1.03]$ \\
\hline Income (log) & $0.89[0.81,0.98]^{\star}$ & $1.06[0.87,1.29]$ \\
\hline \multicolumn{3}{|l|}{ Countries } \\
\hline France & $0.07[0.00,1.00]$ & \\
\hline Italy & $0.05[0.01,0.70]^{\star}$ & \\
\hline Portugal & $0.14[0.01,1.95]$ & \\
\hline Spain & $0.09[0.01,1.21]$ & \\
\hline Czech Republic & & $0.00[0.00,0.00]^{* * *}$ \\
\hline Estonia & & $0.00[0.00,0.00]^{\star * *}$ \\
\hline Hungary & & $0.00[0.00,0.00]^{\star \star *}$ \\
\hline Poland & & $0.00[0.00,0.00]^{\star \star *}$ \\
\hline $\mathrm{n}$ & 1,934 & 2,563 \\
\hline Pseudo $R^{2}$ & $0.07^{* * *}$ & $0.15^{\star \star *}$ \\
\hline
\end{tabular}

Source: Own elaboration based on the Survey of Health, Ageing and Retirement in Europe (SHARE) Wave 4. Weighted data. Estimates significant at the following levels are in boldface: ${ }^{*} p<.05,{ }^{* *} p<.01,{ }^{* \star *} p<.001$.

contradict the assertion of the second hypothesis. Organised Corporatism and Social Partnership regimes were expected to show weaker associations between psychosocial work factors and poor self-perceived health compared to Mixed or Transitional and State-Centred groups. Results supported the opposite phenomenon, where the former cases displayed the strongest work stress associations with poor 
health; while the latter ones, the weakest relationships. In the following section, we analyse these findings in greater detail.

\section{Discussion}

This study used data from the SHARE survey to explore associations between several psychosocial work factors and health condition in the form of self-perceived health among the older workforce in Europe. In addition, we attempted to compare these links between different groups of countries based on industrial or employment relations arrangements. Work stress factors were based on two influential theoretical/conceptual models: the demand-control model and the effort-reward model. Yet, unlike previous research, work stress factors were analysed individually rather than in a composite index to examine the unique contribution of each indicator on levels of self-rated health. A first stage compared the associations of variables between countries clustered in industrial relations regimes with countries assessed individually. Results of logistic regressions highlighted the significant association of perceiving low job security with poor self-rated health among the older workforce, which was consistent in the two compared models. That the association remained slightly the same suggests that among the sampled countries, job insecurity is related to older workers' health across countries and across groups of countries. However, the slight decrease of predictive strength experienced in the regimes models compared to the countries model suggests a higher accuracy of the association in the case of the latter. In fact, differing variability could be observed among countries belonging to the same regime, from a relative homogeneity among the Nordic countries to a relative heterogeneity in the Corporatist Western European countries. In other words, regarding the study of psychosocial work factors and its health implications for the older working people, more precise estimations can be achieved with respect to Eastern, Central, and Western European countries if analysed in a disaggregated manner rather than clustered.

A following stage analysed the association of interest within each industrial relations regime to examine the particular work stress factors affecting the health of the older workforce in those countries. Overall, different psychosocial work risks were found to be related to poor health status in each one of the groups of countries; yet, in all of them, only one out of nine possible stressors showed acceptable levels of significance. Although a more modest result than expected, this reveals which concrete workplace stress factor is most importantly linked to the subjective health of workers in each group of countries. In addition, different combinations of sociodemographic variables had a role in these relationships. In the Organised Corporatism regime, living with a 
registered union and the number of education in years were found to play a part in poor health status; in the Social Partnership group a gendered dimension was foundbeing male-; in the State-Centred countries the socioeconomic factors played an important role-education and income-as well as did age; and in the Mixed or Transitional group it was age the most important variable of this kind. Although most of these variables behaved in an expected way-that is, poor subjective health more likely among the older, the non-married or not in a union, the less educated, and the illpaid-their importance was distributed differently among these groups.

Regarding the hypotheses tested in this study, results found partial to no support of findings reported in previous investigations. The expectation of the first hypothesis was to find a greater prominence of effort and reward factors compared to control factors in the associations with older workers' poor health. Most of the time, variables belonging to the reward dimension of the effort-reward model were significantly linked to poor health in both the pooled and the segregated analyses. This goes along with the literature that found a greater impact of the effort-reward model on several health outcomes among the older working population (Dragano et al. 2011; Hoven et al. 2015; Lunau et al. 2013; Wahrendorf et al. 2013). Job insecurity was the sole significant predictor in the pooled analysis, in the Social Partnership and in the Mixed or Transitional regimes. As suggested in the literature, this may be related to macro-level circumstances such as a dearth of alternative market opportunities for the older workers, especially in countries with a high unemployment rate (Dragano et al. 2011; Eurofound and EU-OSHA 2014; Lunau et al. 2013; Siegrist and Wahrendorf 2011). The fear of losing one's job may influence perceptions of job insecurity, and the threat of long-term unemployment is particularly more incisive among workers 50 years old or over than for younger working cohorts. The association between experienced job insecurity and poor health status could be elevated if in the political-economical climate, changes in employment protection legislation are made-although it remained out of the scope of this study to test this possibility.

The perception of not being paid accordingly to the work done was significantly related to poor health in the State-Centred countries. This is yet another indicator of the reward dimension. This variable in conjunction with less years of education and low level of earnings from work make a clear story of the socioeconomic links to unhealthy conditions of the older workforce. Some of the literature stated the existence of a gender dimension regarding perceptions of satisfactoriness of salary (Eurofound and EU-OSHA 2014). Older male workers tend to perceive more favourably their payment level compared to their younger counterparts; yet, this trend has been found to be quite the opposite in the case of working females. Further research may do well addressing this issue. Finally, poor job latitude was the sole predictor of poor self-rated health in the Organised Corporatism regime; which encompasses the only case in which a factor belonging to the control dimension exerted a significant relation with health outcomes in this study. This comes somewhat unexpected considering the macro-level labour-related circumstances present in these countries: high union density, high 
collective bargaining coverage, and high interaction with the state are some of its common features. Although these macro-level variables were not tested, a possible explanation might rest on a displacement of expectations concerning work arrangements from materialistic to self-realisation levels-in line with the postmaterialism theory (Inglehart 1990). In work-related protective contexts, it is likely that basic features of employment relations are satisfied such as secure working environments, physically safe conditions, limited overwork, better working schedules, or well paid jobs. In such conditions, the factors that could drive dissatisfaction and work stress could belong to a higher order of interests, such as freedom to decide how to organise one's own work, opportunities to channel opinions and feedback to employers, and other factors. However, this remains merely a speculation that could be assessed in further research steps.

The second hypothesis was expecting to find stronger work stress-poor health relation among older workers in Mixed or Transitional and State-Centred regimes, and weaker ties in Social Partnership and Organised Corporatism regimes. Final results give no support to this hypothesis and to findings in previous research (Dragano et al. 2011). To begin with, the average distribution of work stress factors in the three dimensions-i.e., effort, reward, and control-was highest in the Mixed or Transitional cluster, followed by State-Centred, Social Partnership, and closed with the Organised Corporatism countries reporting the lowest proportions of work stress factors taken as dimensions. Nonetheless, multivariate analyses showed that the work stress-poor health associations was stronger in the Social Partnership and Organised Corporatism regimes, and more feeble in the Mixed or Transitional and State-Centred regimes-in that order. As previously said, in all four regimes there was only one work stress indicator sufficiently significant in predicting poor self-rated health; meaning, the Eastern and Mediterranean countries were not related to a higher amount of work stress factors affecting the health of older workers. Rather, the strength of the associations found was more pronounced in the Western and Nordic countries. The implication of this finding is that, when tested in a disaggregated way, the effort-reward and low control models do not support the literature that finds the Scandinavian countries as the less affected in terms of health due to psychosocial work factors and the Southern Europe countries as one of the most affected by them.

\section{Limitations}

The findings of this paper have several limitations that must be stressed. First, the cross-sectional design used does not allow for any attempt of setting causality links between the variables of interest. Further developments applying more sophisticated 
analysis, such as longitudinal approaches, may well yield improved results so to track the associations of interest at several points in time. Additionally, multilevel analyses may account better for the different levels the social groups are nested in. However, such analysis should necessarily entail defining countries as the highest level of analysis rather than groups of countries or regimes. This is so to fulfil the requirement of using a large number of higher level groups that the technique demands. Second, an important remark should be noted regarding the potential biased results provided due to the unit selection process. The analysis was restrained to older people up to 65 years old declaring engagement in paid activity in the labour market at the moment of the interview; hence, discarding the unemployed, retired, permanently disabled, and homemakers who could have been paid workers in previous years. Therefore, the analysis conducted does not assess the association of psychosocial work related factors and self-rated health in general, and is only valid for those in a sufficiently healthy condition to be active in the labour market. Accounts for the "healthy worker effect" should be addressed in the development of the topic in future research.

Third, another source of potential bias is reverse causation, that is, people that perceive their health as poor may have taken jobs with worse working conditions expressed in any of the indicators used for psychosocial work risks. This could be avoided by using prospective designs, which could be implemented in further analyses. Fourth, the survey used might not represent the optimal source to assess work stress factors since it includes only an excerpt-although essential-of the original scale. Moreover, it was not possible to test the demand-control model since there were no indicators available pertaining to the demand dimension. Fifth, although self-perceived health-a clearly subjective measure-has been found to correlate satisfactorily with objective measures of health conditions, it is still recommended by many scholars to complement with objective indicators of health status. Sixth, the models used could be further improved by including contextual variables that control the behaviour of the relationships of interest-e.g., GDP, unemployment rate, lifelong learning prevalence, unemployment benefits, public health expenditure. As a last point, Siegrist (1996) stresses the need to pay attention to private and social life influences on the psychosocial work factors links with health. This goes in line with claims from other scholars regarding the need to account for living conditions and organisational settlements (Benavides, Benach and Muntaner 2002; Elovainio et al. 2002). Further steps in research would do well in incorporating the measurements described thus far.

Conversely, this paper has some strengths that should be noted. First, it takes an innovative approach regarding the use of the influential demand-control and effortreward models. The vast majority of studies have implemented these models in the forms of rations or sum indexes. This time, each dimension was disaggregated by the indicators that compose them and were tested separately as independent variables to observe the relationships with the dependent variable. This allowed observing in detail which of the composing variables was more and less important in predicting poor selfperceived health. Second, very few of the literature reviewed engaged in comparisons 
across country types when examining the relationship between work stress factors and health outcomes in the older worker population. Most studies analyse European countries in a pooled fashion, whereas in this paper countries were classified according to a labour-related typology present in the literature. In addition, the application of typologies other than the welfare state is rare in this topic, which gives an innovative aspect to the paper.

\section{Conclusion}

This study shows that different psychosocial work factors are related to the health of the older workforce in Europe. Moreover, depending on the type of country, the relevance of several work stress factors varies in this association. The implications are a matter of policy concern in order to preserve the health condition of middle to later life workers. This research gives further support to the notion that tailor-made health and labour policies in the workplace should be designed to prevent deterioration of workers' health so to extend their participation in the workforce. This is particularly important for countries expecting a growth in their older population and old-age dependency ratio in the years to come.

\section{Bibliographic references}

ARTS, W.; GELISSEN, J. (2002). "Three worlds of welfare capitalism or more? A stateof-the-art report". Journal of European Social Policy. Vol. 12, No. 2, pages 137158.

BENACH, J.; MUNTANER, C.; SOLAR, O.; SANTANA, V.; QUINLAN, M. (2013). Employment, Work and Health Inequalities: A Global Perspective. Barcelona, Spain: Icaria.

BENACH, J.; VIVES, A.; AMABLE, M.; VANROELEN, C.; TARAFA, G.; MUNTANER, C. (2014). "Precarious employment: Understanding an emerging social determinant of health". Annual Review of Public Health. Vol. 35, pages 229-253.

BENAVIDES, F.G.; BENACH, J.; MUNTANER, C. (2002). "Psychosocial risk factors at the workplace: Is there enough evidence to establish reference values?". Journal of Epidemiology \& Community Health. Vol. 56, pages 244-245. 
BERG, T.V.D.; SCHURING, M.; AVENDANO, M.; MACKENBACH, J.; BURDORF, A. (2010). "The impact of ill health on exit from paid employment in Europe among older workers". Occupational \& Environmental Medicine. Vol. 67, No. 12, pages 845-852.

BÖRSCH-SUPAN, A. (2013). Survey of Health, Ageing and Retirement in Europe (SHARE) Wave 4. Release version: 1.1.1. SHARE-ERIC [Dataset].

BÖRSCH-SUPAN, A.; BRANDT, M.; HUNKLER, C.; KNEIP, T.; KORBMACHER, J.; MALTER, F.; SCHAAN, B.; STUCK, S.; Zuber, S. (2013). "Data resource profile: The Survey of Health, Ageing and Retirement in Europe (SHARE)". International Journal of Epidemiology. Vol. 42, No. 4, pages 992-1001.

COMMISSION ON SOCIAL DETERMINANTS OF HEALTH. (2008). Closing the Gap in a Generation: Health Equity Through Action on the Social Determinants of Health. Final Report of the Commission on Social Determinants of Health. Geneva, Switzerland: World Health Organization.

DEBRAND, T.; LENGAGNE, P. (2008). "Working conditions and health of European older workers". IRDES. (Document de Travail; 8).

DOLLARD, M.F.; NESER, D.Y. (2013). "Worker health is good for the economy: Union density and psychosocial safety climate as determinants of country differences in worker health and productivity in 31 European countries". Social Science \& Medicine. Vol. 92, pages 114-123.

DRAGANO, N.; SIEGRIST, J.; WAHRENDORF, M. (2011). "Welfare regimes, labour policies and unhealthy psychosocial working conditions: A comparative study with 9917 older employees from 12 European countries". Journal of Epidemiology \& Community HealtH. Vol. 65, No. 9, pages 793-799.

EBBINGHAUS, B. (2006). Reforming Early Retirement in Europe, Japan and the USA. New York, NY: Oxford Scholarship Online.

ELOVAINIO, M.; KIVIMÄKI, M.; VAHTERA, J. (2002). "Organizational justice: Evidence of a new psychosocial predictor of health". American Journal of Public Health. Vol. 92, No. 1, pages 105-108.

ESPING-ANDERSEN, G. (1990). The Three Worlds of Welfare Capitalism. Cambridge, United Kingdom: Polity Press.

EUROFOUND. (2012a). Employment Trends and Policies for Older Workers in the Recession. Dublin, Ireland: Eurofound.

EUROFOUND. (2012b). Sustainable Work and the Ageing Workforce. Luxembourg: Publications Office of the European Union. 
EUROFOUND. (2013). Role of Governments and Social Partners in Keeping Older Workers in the Labour Market. Dublin, Ireland: Eurofound.

EUROFOUND; EU-OSHA. (2014). Psychosocial Risks in Europe: Prevalence and Strategies for Prevention. Luxembourg: Publications Office of the European Union.

EUROPEAN COMMISSION. (2008). Industrial Relations in Europe 2008. Brussels, Belgium: Office for Official Publications of the European Communities.

EUROPEAN COMMISSION. (2013). Industrial Relations in Europe 2012. Luxembourg: Publications Office of the European Union.

EUROSTAT. (2013). "Healthy life years" (from 2004 onwards) (hlth_hlye) [Online data set]. [Date of query: June 2, 2015].

FRENCH, J.R.P.; CAPLAN, R.D.; HARRISON, R.V. (1982). The Mechanisms of Job Stress and Strain. Chichester, United Kingdom: Wiley.

GALLIE. D. (2011). Production Regimes, Employee Job Control and Skill Development. Oxford, United Kingdom: Centre for Learning and Life Chances in Knowledge Economies and Societies.

HOONAKKER, P.; DUIVENBOODEN, C.V. (2010). "Monitoring working conditions and health of older workers in Dutch construction industry". American Journal of Industrial Medicine. Vol. 53, No. 6, pages 641-653.

HOVEN, H.; WAHRENDORF, M.; SIEGRIST, J. (2015). "Occupational position, work stress and depressive symptoms: A pathway analysis of longitudinal SHARE data". Journal of Epidemiology \& Community Health. No. 0, pages 1-6.

IDLER, E.L.; BENYAMINI, Y. (1997). "Self-rated health and mortality: A review of twenty-seven community studies". Journal of Health and Social Behavior. Vol. 38, No. 1, pages 21-37.

INGLEHART, R. (1990). Culture Shift in Advanced Industrial Society. NJ: Princeton University Press.

JAGGER, C.; GILLIES, C.; MOSCONE, F.; CAMBOIS, E.; VAN OYEN, H.; NUSSELDER, W.; ROBINE, J.-M. (2008). "Inequalities in healthy life years in the 25 countries of the European Union in 2005: A cross-national meta-regression analysis". The Lancet. Vol. 372, No. 9656, pages 2124-2131.

JONES, M.K.; LATREILLE, P.L.; SLOANE, P.J.; STANEVA, A.V. (2011). "Work-related health in Europe: Are older workers more at risk?". IZA Discussion Paper Series. (IZA DP; 6044). 
JONES, M.K.; LATREILLE, P.L.; SLOANE, P.J.; STANEVA, A.V. (2013). "Work-related health risks in Europe: Are older workers more vulnerable?". Social Science \& Medicine. Vol. 88, pages 18-29.

KALOUSOVA, L.; MENDES DE LEON, C. (2015). "Increase in frailty of older workers and retirees predicted by negative psychosocial working conditions on the job." Social Science \& Medicine. Vol. 124, pages 275-283.

KARASEK, R.; THEORELL, T. (1990). Healthy Work: Stress, Productivity, and the Reconstruction of Working Life. New York, NY: Basic Books.

KEESE, M.; OECD. (2006). Live Longer, Work Longer. Ageing and Employment Policies. Paris, France: OECD Publishing.

LUNAU, T.; WAHRENDORF, M.; DRAGANO, N.; SIEGRIST, J. (2013). "Work stresS and depressive symptoms in older employees: Impact of national labour and social policies". BMC Public Health. Vol. 13, No. 1086.

MALTER, F.; BÖRSCH-SUPAN, A. (eds.). (2013). SHARE Wave 4: Innovations \& Methodology. Munich, Germany: MEA, Max Planck Institute for Social Law and Social Policy.

MYCK, M. (2015). "Living longer, working longer: The need for a comprehensive approach to labour market reform in response to demographic changes". European Journal of Ageing. Vol. 12, No. 1, pages 3-5.

OECD. (2010). Mental Health, Disability and Work: Issues for Discussion. Paris, France. (OECD Expert Meeting).

PIKHART, H.; BOBAK, M.; SIEGRIST, J.; PAJAK, A.; RYWIK, S.; KYSHEGYI, J.; GOSTAUTAS, A.; SKODOVA, Z.; MARMOT, M. (2001). "Psychosocial work characteristics and self rated health in four post-communist countries". Journal of Epidemiology \& Community Health. Vol. 55, No. 9, pages 624-630.

POLLAK, C. (2012). "Employed and happy despite weak health? Labour market participation and job quality of older workers with disabilities". IRDES. (Document de Travail; 45).

REINHARDT, J.D.; WAHRENDORF, M.; SIEGRIST, J. (2013). "Socioeconomic position, psychosocial work environment and disability in an ageing workforce: A longitudinal analysis of SHARE data from 11 European countries". Occupational \& Environmental Medicine. Vol. 70, No. 3, pages 156-63.

ROBROEK, S.J.W.; SCHURING, M.; CROEZEN, S.; STATTIN, M.; BURDORF, A. (2013). "Poor health, unhealthy behaviors, and unfavorable work characteristics influence pathways of exit from paid employment among older workers in Europe: A four year follow-up study". Scandinavian Journal of Work, Environment \& Health. Vol. 39, No. 2, pages 125-133. 
SIEGRIST, J. (1996). "Adverse health effects of high-effort/low-reward conditions". Journal of Occupational Health Psychology. Vol. 1, No. 1, pages 27-41.

SIEGRIST, J.; MONTANO, D.; HOVEN, H. (2014). Working Conditions and Health Inequalities, Evidence and Policy Implications. Germany: Heinrich HeineUniversität Düsseldorf.

SIEGRIST, J.; WAHRENDORF, M. (2011). "Quality of work, health and early retirement: European comparisons". In: BÖRSCH-SUPAN, A.; BRANDT, M.; HANK, K.; SCHRÖDER, M. (eds.). The Individual and the Welfare State: Life Histories in Europe. Heiderlberg, Germany: Springer, pages 169-177.

SIEGRIST, J.; WAHRENDORF, M.; KNESEBECK, O.V.D.; JÜRGES, H.; BÖRSCHSUPAN, A. (2007). "Quality of work, well-being, and intended early retirement of older employees - Baseline results from the SHARE Study". European Journal of Public Health. Vol. 17, No. 1, pages 62-68.

SOLÉ-AURÓ, A.; ALCAÑIZ, M. (2015). "Are we living longer but less healthy? Trends in mortality and morbidity in Catalonia (Spain), 1994-2011". European Journal of Ageing. Vol. 12, No. 1, pages 61-70.

UNITED NATIONS, DEPARTMENT OF ECONOMIC AND SOCIAL AFFAIRS, POPULATION DIVISION. (2013). World Population Prospects: The 2012 Revision. New York, NY: United Nations.

VENDRAMIN, P.; VALENDUC, G. (2012). "Occupations and ageing at work: An analysis of the findings of the fifth European Working Conditions Survey". European Trade Union Institute. (Working Paper; 2012.09).

WAHRENDORF, M.; DRAGANO, N.; SIEGRIST, J. (2013). "Social position, work stress, and retirement intentions: A study with older employees from 11 European countries". European Sociological Review. Vol. 29, No. 4, pages 792-802. 


\section{Annex}

\section{Definition of Psychosocial Work Factors}

\section{Effort Dimension}

- (Q1) My job is physically demanding. Would you say you strongly agree, agree, disagree or strongly disagree?

- (Q2) I am under constant time pressure due to a heavy workload. Would you say you strongly agree, agree, disagree or strongly disagree?

\section{Reward Dimension}

- (Q1) I receive the recognition I deserve for my work. Would you say you strongly agree, agree, disagree or strongly disagree?

- (Q2) Considering all my efforts and achievements, my salary is adequate. Would you say you strongly agree, agree, disagree or strongly disagree?

- (Q3) My job promotion prospects are poor. Would you say you strongly agree, agree, disagree or strongly disagree?

- (Q4) My job security is poor. Would you say you strongly agree, agree, disagree or strongly disagree?

\section{Control Dimension}

- (Q1) I receive adequate support in difficult situations. Would you say you strongly agree, agree, disagree or strongly disagree?

- (Q2) I have very little freedom to decide how I do my work. Would you say you strongly agree, agree, disagree or strongly disagree?

- (Q3) I have an opportunity to develop new skills. Would you say you strongly agree, agree, disagree or strongly disagree? 


\section{Resumen}

Utilizando datos de 15 países europeos de la Encuesta de Salud, Envejecimiento y Jubilación en Europa (SHARE), exploro la asociación entre diferentes factores psicosociales en el trabajo y la salud autopercibida entre los trabajadores $y$ trabajadoras de más edad (50 a 65 años) ( $n=12.728)$. Tomando como referencia los modelos de desequilibrio entre esfuerzo-recompensa y de bajo nivel de control, elaboro las siguientes hipótesis: (a) los factores esfuerzo y recompensa son predictores más relevantes de estados de salud pobres en comparación con el factor control en Europa; y (b) estas asociaciones son más fuertes en los contextos relativemente menos protegidos a nivel laboral como Europa del este y los países mediterráneos, y más débiles en los contextos más protectores como Europa continental occidental y los países escandinavos. Después de diferentes análisis de regresión logística, los resultados mostraron que los componentes del factor recompensa fueron los predictores más relevantes en tres de las cuatro regiones; $y$ que los países escandinavos y de Europa continental occidental evidenciaron la asociación más fuerte entre estrés laboral y estado de salud pobre. Estos hallazgos destacan la importancia de promover políticas laborales y de salud "a la medida" que permitan a los trabajadores y trabajadoras de más edad permanecer más tiempo en el mercado de trabajo en vista del creciente envejecimiento de la población.

\section{Palabras clave}

Trabajadores/as mayores, Factores psicosociales del trabajo, Estrés laboral, Salud autopercibida, Europa. 


\section{Resum}

Utilitzant dades de 15 països europeus de l'Enquesta de Salut, Envelliment $i$ Jubilació a Europa (SHARE), examino l'associació entre diferents factors psicosocials laborals $i$ la salut autopercebuda dels treballadors i treballadores grans (entre 50 i 65 anys) ( $n=$ 12.728). Prenent com a referència els models de desequilibri entre esforç-recompensa $i$ de baix nivell de control, estableixo com a hipòtesis (a) que els factors esforç $i$ recompensa són predictors més rellevants d'estats de salut pobres en comparació amb el factors control a Europa; $i$ (b) que aquestes associacions són més pronunciades als contextos relativament menys protegits laboralment com a Europa de l'est $i$ els països mediterranis, i més febles als contextos més protectors com a Europa continental occidental i els països escandinaus. Després de diferents anàlisis de regressió logística, els resultats ensenyen que els components del factor recompensa van ser els predictors més rellevants en tres de les quatre regions; i que els països escandinaus i d'Europa continental occidental van presentar l'associació més forta entre estrès laboral $i$ estat de salut pobre. Aquestes troballes recalquen la importància de promoure polítiques laborals $i$ de salut a la mida que permetin als treballadors i treballadores grans romandre al mercat laboral per més temps donat el creixent envelliment de la població.

\section{Paraules clau}

Treballadors/es grans, Factors psicosocials laborals, Estrès laboral, Salut autopercebuda, Europa. 


\section{Daniel Blanche}

dblanchet@uoc.edu

Internet Interdisciplinary Institute (IN3)

Open University of Catalonia

Daniel Blanche is BA in Communications from the Universidad del Pacifico (Chile), MRes in Sociology from the University of Barcelona, and MRes in Demography and Sociology from Pompeu Fabra University. Assistant researcher at the Mobile Technologies and (G)Local Challenges research group (GLocalMob), he has conducted research on older people, social movements and ICT. His interests lay on the interrelations between employment and working arrangements and health conditions of the population, with an emphasis in social inequalities and age groups. More info: $h$ ttp://glocalmobile.cat/en/daniel-blanche/

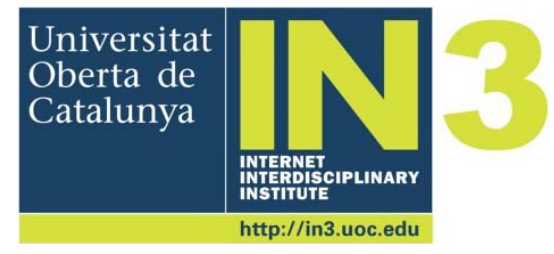

